ISSN : $2450-766 X$

\title{
FAKTOR-FAKTOR YANG MEMPENGARUHI KONSUMEN DALAM KEPUTUSANPEMBELIAN SEPEDA MOTOR HONDA PADA CV. ANUGERAH PERDANA MONGINSIDI PALU DENGAN MENGGUNAKAN KOEFISIEN KONTINGENSI
}

\author{
H. M. Rancendo ${ }^{1}$, Nur'eni $^{2}$, I. T. Utami ${ }^{3}$ \\ 1Program Studi Matematika Jurusan Matematika FMIPA Universitas Tadulako \\ Jalan Soekarno-Hatta Km. 09 Tondo, Palu 94118, Indonesia. \\ 2,3Program Studi Statistik Jurusan Matematika FMIPA Universitas Tadulako \\ Jalan Soekarno-Hatta Km. 09 Tondo, Palu 94118, Indonesia. \\ 1hettymeike@yahoo.com, 2eniocy@yahoo.com,3triutami.iut@gmail.com
}

\begin{abstract}
Purchase decision is an act of consumers to buy a product or not. This decision is influenced by the quality of their factors both internal and external factors. The study was conducted to determine whether cultural factors, personal, psychological and social simultaneously influence the purchasing decisions of Honda motorcycles. The method used in this research is to test the contingency coefficient, which the contingency coefficient test has close links with the chi square test. The results obtained show the external factors simultaneously have a significant influence on purchasing decisions Honda motorcycles. This is indicated by the probability of these four factors is smaller than the significance level (0.05). The most dominant influence in purchasing decisions Honda motorcycle is because the psychological factor has a value of $\mathrm{C}=0.704$ approach $\mathrm{C} \_$Max value. $=0.866$.
\end{abstract}

Keywords : : Chi-Square, Contingency Coefficient, Cultural Factors, Personal Factors, Psychological Factors, Social Factors and Purchase Decision.

\begin{abstract}
ABSTRAK
Keputusan pembelian adalah suatu tindakan dari konsumen untuk membeli atau tidak suatu produk. Keputusan ini di pengaruhi oleh faktor kulitas baik faktor internal maupun eksternal. Penelitian dilakukan untuk mengetahui apakah faktor budaya, pribadi, psikologis dan sosial secara simultan berpengaruh dalam keputusan pembelian sepeda motor Honda. Metode yang digunakan dalam penelitian ini adalah uji koefisien kontingensi, dimana uji koefisien kontingensi mempunyai kaitan erat dengan uji chi kuadrat. Hasil yang diperoleh menunjukan faktor eksternal secara simultan mempunyai pengaruh signifikan dalam keputusan pembelian sepeda motor Honda. Hal ini di tunjukan oleh nilai peluang dari keempat faktor tersebut lebih kecil dari taraf signifikan $(0,05)$. Pengaruh paling dominan dalam keputusan pembelian sepeda motor Honda adalah faktor psikologis karna memiliki nilai $C$ $=0,704$ mendekati nilai $C_{\text {Max }}=0,866$.
\end{abstract}

Kata Kunci : $\quad$ Chi-Kuadrat, Faktor Kebudayaan, Faktor Pribadi, Faktor Psikologis, Faktor Sosial dan Keputusan Pembelian, Koefisien Kontingensi. 


\section{PENDAHULUAN}

Dalam perkembangan kehidupan yang semakin dinamis ini, kebutuhan akan alat transportasi sudah menjadi sebuah hal yang mutlak harus dipenuhi, tujuannya adalah agar setiap manusia tetap mampu menyelesaikan semua kegiatan mereka yang menuntut kecepatan dan ketetapan waktu. Salah satu perusahaan pembuat sepeda motor yang terbesar di Indonesia adalah Honda.

Keputusan pembelian terhadap suatu barang sangat dipengaruhi oleh faktor kulitas baik faktor internal seperti strategi penetapan harga oleh Honda maupun faktor eksternal seperti faktor kebudayaan, faktor pribadi, faktor psikologis dan faktor sosial juga perlu diperhatikan mengingat dewasa ini informasi, tanggapan yang relatif homogen dan permanen yang tersusun dan yang anggotanya menganut nilai-nilai, minat, dan perilaku yang bertahan lama terhadap lingkungan dimana ia tinggal dan hidup pada waktu sekarang tanpa mengabaikan pengaruh dimasa lampau.

Melihat dari faktor-faktor pengaruh, maka diperlukan suatu analisis statistik untuk dapat menjelaskan faktor kualitas konsumen terhadap keputusan pembelian sepeda motor Honda di kota Palu dengan menggunakan metode koefisien kontingensi.

Metode koefisien kontingensi mempunyai fungsi utama untuk menampilkan informasi berkaitan dengan faktor-faktor kualitas yang sangat mempengaruhi keputusan pembelian sepeda motor Honda yang menurut konsumen perlu ditingkatkan karena kondisi saat ini belum memuaskan.

\section{METODE PENELITIAN}

\subsection{Lokasi dan Penelitian}

Lokasi penelitian ini dilakukan di kota Palu dengan objek konsumen pengguna motor Honda pada CV. Anugrah Perdana Monginsidi dan pengolahan dilakukan di Laboratorium Statistik Matematika Fakultas MIPA Jurusan Matematika UNTAD.

\subsection{Alat dan Bahan Penelitian}

Alat dan bahan yang digunakan dalam penelitian ini adalah alat tulis-menulis, alat ukur berupa daftar pertanyaan (kuesioner) dan laptop untuk menghitung jumlah data.

\subsection{Sumber dan Jenis Data}

Data yang digunakan dalam penelitian ini adalah data primer, dimana data yang diperoleh langsung dari objek penelitian atau responden. Jenis data yang digunakan dalam penelitian ini adalah data kualitatif, dimana data yang berupa label atau nama-nama yang digunakan untuk mengidentifikasikan atribut atau elemen. 


\subsection{Populasi dan Sampel Penelitian}

Penelitian yang menggunakan metode survey, tidak harus meneliti seluruh individu dalam populasi yang ada, karena akan membutuhkan biaya yang besar dan juga waktu yang lama. Penelitian dapat dilakukan dengan meneliti sebagian dari populasi (sampel). Dalam menetapkan besarnya sampel (sampel size) dalam penelitian ini didasarkan pada perhitungan yang dikemukakan oleh Slovin dalam Husein Umar (2003 : 146) sebagai berikut :

$n=\frac{N}{N e^{2}+1}$

dengan :

$n$ = banyaknya Sampel

$N=$ Jumlah Populasi

$e=$ Persen kelonggaran ketidaktelitian karena kesalahn pengambilan sampel yang masih dapat ditolerir atau diinginkan sebanyak $10 \%$.

\subsection{Teknik Pengumpulan Data}

Data yang diperoleh dari jawaban kuesioner adalah bersifat kualitatif, maka data tersebut perlu dikuantitatifkan terlebih dahulu. Oleh karena itu, maka setiap jawaban yang diperoleh diberi skor dengan menggunakan skala Likert.

\subsection{Teknik Pengumpulan Data}

Teknik analisa data yang digunakan dalam penelitian ini adalah menggunakan metode koefisien kontingensi.

\subsection{Prosedur Penelitian}

Prosedur pengolahan Data pada penelitian ini adalah Pengumpulan data, Uji Validitas dan Uji Reliabilitas, Jika data tidak valid dan reliabel maka pertanyaan yang tidak valid dan reliabel dihilangkan dalam kuesioner, Jika sudah valid dan reliabel maka dapat dilanjutkan, Uji Chi kuadrat, menghitung koefisien kontingensi, Kesimpulan / Interpretasi hasil.

\section{HASIL DAN PEMBAHASAN}

\subsection{Hasil Penelitian}

Pengumpulan data dalam penelitian ini adalah dengan menggunakan kuesioner sebagai pengumpul data pokok.

$n=\frac{4837}{4837(10 \%)^{2}+1}$

$$
=97,97 \sim 100
$$




\subsubsection{Uji Validitas}

Pengujian validitas masing -masing pertanyaan menggunakan korelasi product moment. Sebuah pertanyaan juga dianggap valid, jika nilai signifikan $\leq \alpha$. Dengan menggunakan $\alpha=5 \%$, terlihat dari hasil output SPSS bahwa keseluruhan pertanyaaan menunjukan nilai sign $=0,000$. Karena $0,000<0,05$, maka seluruh pertanyaan dalam penelitian ini semuanya valid.

\subsubsection{Uji Realibilitas}

Pengujian reliabilitas dihitung mengunakan rumus "Spearman Brown" dengan teknik belah dua atau dibagi berdasarkan nomor genap dan ganjil, dihitung korelasi antara total nomor ganjil dengan total nomor genap.

$r_{b}=\frac{100(96815)-(3190)(3005)}{\sqrt{\left\{100(103156)-(3190)^{2}\right\}\left\{100(91793)-(3005)^{2}\right\}}}=0,662$

Jadi nilai reliabilitas keseluruhan pertanyaan di atas adalah :

$r_{i}=\frac{2 r_{b}}{1+r_{b}}=\frac{2(0,662)}{1+0,662}=\frac{1,342}{1,662}=0,796$

\subsection{Uji Chi-Kuadrat}

Uji Chi-Kuadrat yang dimaksudkan adalah menguji hipotesis yang ada, apakah terdapat pengaruh faktor budaya, faktor pribadi, faktor psikologis dan sosial dalam keputusan pembelian sepeda motor Honda di CV. Anugrah Perdana Monginsidi Palu.

\subsubsection{Keputusan Penelitian}

Keputusan pembelian yang diteliti dalam penelitian ini meliputi : faktor kebudayaan, faktor pribadi, faktor psikologisdan faktor sosial.

Tabel 1 : Frekuensi Observasi Pengaruh Faktor Budaya

\begin{tabular}{|c|c|c|c|c|c|c|c|}
\hline & \multirow{2}{*}{ Budaya } & \multicolumn{5}{|c|}{ Keputusan Pembelian } & \multirow{2}{*}{ Total } \\
\hline & & sS & $\mathrm{s}$ & $\mathrm{N}$ & TS & STN & \\
\hline \multirow{5}{*}{1} & Sangat Populer & 15 & 11 & 5 & 0 & 0 & 31 \\
\hline & Populer & 11 & 22 & 10 & 2 & 1 & 46 \\
\hline & Cukup Populer & 6 & 9 & 4 & 1 & 0 & 20 \\
\hline & Tidak Populer & 0 & 1 & 1 & 0 & 0 & 2 \\
\hline & Sangat Tidak Populer & 0 & 0 & 1 & 0 & 0 & 1 \\
\hline \multicolumn{2}{|c|}{ Total } & 32 & 43 & 21 & 3 & 1 & 100 \\
\hline \multirow{5}{*}{2} & Sangat Populer & 22 & 13 & 3 & 1 & 0 & 39 \\
\hline & Populer & 2 & 16 & 7 & 1 & 1 & 27 \\
\hline & Cukup Populer & 8 & 12 & 8 & 1 & 0 & 29 \\
\hline & Tidak Populer & 0 & 2 & 2 & 0 & 0 & 4 \\
\hline & Sangat Tidak Populer & 0 & 0 & 1 & 0 & 0 & 1 \\
\hline \multicolumn{2}{|c|}{ Total } & 32 & 43 & 21 & 3 & 1 & 100 \\
\hline
\end{tabular}




\begin{tabular}{|c|l|c|c|c|c|c|c|}
\multirow{5}{*}{3} & 11 & 9 & 7 & 2 & 0 & 29 \\
\cline { 2 - 8 } & Sangat Populer & 11 & 20 & 8 & 1 & 0 & 40 \\
\cline { 2 - 8 } & Populer & 7 & 11 & 6 & 0 & 0 & 24 \\
\cline { 2 - 8 } & Cukup Populer & 3 & 3 & 0 & 0 & 1 & 7 \\
\cline { 2 - 8 } & Tidak Populer & 0 & 0 & 0 & 0 & 0 & 0 \\
\cline { 2 - 8 } & Sangat Tidak Populer & 32 & 43 & 21 & 3 & 1 & 100 \\
\hline \multicolumn{2}{|l|}{ Total } & & & & &
\end{tabular}

Dari ketiga pertanyaan di atas didominasi oleh jawaban setuju, yaitu sejumlah masing-masing 43 responden. Hal ini menunjukan bahwa responden pada umumnya menyatakan setuju jika membeli sepeda motor Honda karena mengikuti perkembangan kebudayaan, sesuai dengan kehidupan sebagai masyarakat modern dan mempertimbangkan merek yang populer saat ini.

Tabel 2 : Frekuensi Harapan Pengaruh Faktor Budaya

\begin{tabular}{|c|c|c|c|c|c|c|c|}
\hline & \multirow{2}{*}{ Budaya } & \multicolumn{5}{|c|}{ Keputusan Pembelian } & \multirow{3}{*}{$\begin{array}{c}\text { Total } \\
31\end{array}$} \\
\hline & & \multirow{2}{*}{$\frac{\text { SS }}{9,92}$} & \multirow{2}{*}{$\frac{S}{13,33}$} & \multirow{2}{*}{$\frac{\mathrm{N}}{6,51}$} & \multirow{2}{*}{$\begin{array}{c}\text { TS } \\
0,93\end{array}$} & \multirow{2}{*}{$\begin{array}{l}\text { STN } \\
0,31\end{array}$} & \\
\hline \multirow{5}{*}{1} & Sangat Populer & & & & & & \\
\hline & Populer & 14,72 & 19,78 & 9,66 & 1,38 & 0,46 & 46 \\
\hline & Cukup Populer & 6,4 & 8,6 & 4,2 & 0,6 & 0,2 & 20 \\
\hline & Tidak Populer & 0,64 & 0,86 & 0,42 & 0,06 & 0,02 & 2 \\
\hline & Sangat Tidak Populer & 0,32 & 0,43 & 0,21 & 0,03 & 0,01 & 1 \\
\hline \multicolumn{2}{|c|}{ Total } & 32 & 43 & 21 & 3 & 1 & 100 \\
\hline \multirow{5}{*}{2} & Sangat Populer & 12,48 & 16,77 & 8,19 & 1,17 & 0,39 & 39 \\
\hline & Populer & 8,64 & 11,61 & 5,67 & 0,81 & 0,27 & 27 \\
\hline & Cukup Populer & 9,28 & 12,47 & 6.09 & 0,87 & 0,29 & 29 \\
\hline & Tidak Populer & 1,28 & 1,72 & 0,84 & 0,12 & 0,04 & 4 \\
\hline & Sangat Tidak Populer & 0,32 & 0,43 & 0,21 & 0,03 & 0,01 & 1 \\
\hline \multicolumn{2}{|c|}{ Total } & 32 & 43 & 21 & 3 & 1 & 100 \\
\hline \multirow{5}{*}{3} & Sangat Populer & 9,28 & 12,47 & 6.09 & 0,87 & 0,29 & 29 \\
\hline & Populer & 12,8 & 17,2 & 8,4 & 1,2 & 0,4 & 40 \\
\hline & Cukup Populer & 7,68 & 10,32 & 5,04 & 0,72 & 0,24 & 24 \\
\hline & Tidak Populer & 2,24 & 3,01 & 1,47 & 0,21 & 0,07 & 7 \\
\hline & Sangat Tidak Populer & 0 & 0 & 0 & 0 & 0 & 0 \\
\hline \multicolumn{2}{|c|}{ Total } & 32 & 43 & 21 & 3 & 1 & 100 \\
\hline
\end{tabular}

Hipotesis : $H_{0}: M=0$ (Tidak pengaruh faktor budaya dalam keputusan pembelian sepeda motor Honda pada CV.Anugrah Perdana Monginsidi Palu dengan menggunakan metode koefisien kontingensi).

$H_{1}: M \neq 0$ (Ada penagruh faktor budaya dalam keputusan pembelian sepeda motor Honda pada CV.Anugrah Perdana Monginsidi Palu dengan menggunakan metode koefisien kontingensi). 
Pasangan hipotesis di atas diuji dengan statistik Chi-Kuadrat. Dengan bantuan program SPSS 16, maka diperoleh nilai Chi-Kuadrat $\left(X^{2}\right)=29.512$.

Tabel 3 : Frekuensi Observasi Pengaruh Faktor Pribadi

\begin{tabular}{|c|c|c|c|c|c|c|c|}
\hline & \multirow{2}{*}{ Pribadi } & \multicolumn{5}{|c|}{ Keputusan Pembelian } & \multirow{3}{*}{$\begin{array}{c}\text { Total } \\
35\end{array}$} \\
\hline & & \multirow{2}{*}{$\begin{array}{l}\text { SS } \\
20\end{array}$} & \multirow{2}{*}{$\frac{S}{10}$} & \multirow{2}{*}{$\frac{N}{3}$} & \multirow{2}{*}{$\begin{array}{c}\text { TS } \\
1\end{array}$} & \multirow{2}{*}{$\frac{\text { STN }}{1}$} & \\
\hline \multirow{5}{*}{1} & Sangat Sesuai & & & & & & \\
\hline & Sesuai & 5 & 14 & 8 & 3 & 1 & 31 \\
\hline & Cukup Sesuai & 8 & 10 & 8 & 0 & 1 & 27 \\
\hline & Tidak Sesuai & 0 & 6 & 0 & 0 & 0 & 6 \\
\hline & Sangat Tidak Sesuai & 0 & 0 & 0 & 1 & 0 & 1 \\
\hline \multicolumn{2}{|c|}{ Total } & 33 & 40 & 19 & 5 & 3 & 100 \\
\hline \multirow{5}{*}{2} & Sangat Sesuai & 7 & 12 & 3 & 2 & 0 & 34 \\
\hline & Sesuai & 11 & 20 & 7 & 1 & 1 & 40 \\
\hline & Cukup Sesuai & 2 & 6 & 6 & 0 & 2 & 16 \\
\hline & Tidak Sesuai & 1 & 2 & 2 & 1 & 0 & 6 \\
\hline & Sangat Tidak Sesuai & 2 & 0 & 1 & 1 & 0 & 4 \\
\hline \multicolumn{2}{|c|}{ Total } & 33 & 40 & 19 & 5 & 3 & 100 \\
\hline \multirow{5}{*}{3} & Sangat Sesuai & 13 & 5 & 5 & 2 & 0 & 25 \\
\hline & Sesuai & 10 & 18 & 5 & 0 & 2 & 35 \\
\hline & Cukup Sesuai & 7 & 13 & 9 & 2 & 0 & 31 \\
\hline & Tidak Sesuai & 3 & 4 & 0 & 0 & 0 & 7 \\
\hline & Sangat Tidak Sesuai & 0 & 0 & 0 & 1 & 1 & 2 \\
\hline \multicolumn{2}{|c|}{ Total } & 33 & 40 & 19 & 5 & 3 & 100 \\
\hline
\end{tabular}

Dari ketiga pertanyaan tersebut didominasi oleh jawaban setuju, yaitu sejumlah masing-masing 40 responden. Hal ini menunjukan bahwa responden pada umumnya menyatakan setuju jika membeli sepeda motor Honda karena sesuai dengan usia kebutuhan, dapat mencerminkan gaya hidup, memberikan adanya rasa percaya diri dan sesuai dengan usia pekerjaan.

Tabel $4 \quad$ : Frekuensi Harapan Pengaruh Faktor Pribadi

\begin{tabular}{|c|c|c|c|c|c|c|c|}
\hline \multirow{2}{*}{\multicolumn{2}{|c|}{ Pribadi }} & \multicolumn{5}{|c|}{ Keputusan Pembelian } & \multirow{3}{*}{$\begin{array}{c}\text { Total } \\
35\end{array}$} \\
\hline & & \multirow{2}{*}{$\begin{array}{c}\text { SS } \\
11,55\end{array}$} & \multirow{2}{*}{$\begin{array}{c}S \\
14\end{array}$} & \multirow{2}{*}{$\begin{array}{c}\mathrm{N} \\
6,65\end{array}$} & \multirow{2}{*}{$\begin{array}{c}\text { TS } \\
1,75\end{array}$} & \multirow{2}{*}{$\begin{array}{l}\text { STN } \\
1,05\end{array}$} & \\
\hline \multirow{5}{*}{1} & Sangat Sesuai & & & & & & \\
\hline & Sesuai & 10,23 & 12,4 & 5,89 & 1,55 & 0,93 & 31 \\
\hline & Cukup Sesuai & 8,91 & 10,8 & 5,13 & 1,35 & 0,81 & 27 \\
\hline & Tidak Sesuai & 1,98 & 2,4 & 1,14 & 0,3 & 0,18 & 6 \\
\hline & Sangat Tidak Sesuai & 0,33 & 0,4 & 0,19 & 0,05 & 0,03 & 1 \\
\hline
\end{tabular}




\begin{tabular}{|c|c|c|c|c|c|c|c|}
\hline \multicolumn{2}{|c|}{ Total } & 33 & 40 & 19 & 5 & 3 & 100 \\
\hline \multirow{5}{*}{2} & Sangat Sesuai & 11,22 & 13,6 & 6,46 & 1,7 & 1,02 & 34 \\
\hline & Sesuai & 13,2 & 16 & 7,6 & 2 & 1,2 & 40 \\
\hline & Cukup Sesuai & 5,28 & 6,4 & 3,04 & 0,8 & 0,48 & 16 \\
\hline & Tidak Sesuai & 1,98 & 2,4 & 1,14 & 0,3 & 0,18 & 6 \\
\hline & Sangat Tidak Sesuai & 1,32 & 1,6 & 0,76 & 1,2 & 0,12 & 4 \\
\hline \multicolumn{2}{|c|}{ Total } & 33 & 40 & 19 & 5 & 3 & 100 \\
\hline \multirow{5}{*}{3} & Sangat Sesuai & 8,25 & 10 & 4,75 & 1,25 & 0.75 & 25 \\
\hline & Sesuai & 11,55 & 14 & 6,65 & 1,75 & 1,05 & 35 \\
\hline & Cukup Sesuai & 10,23 & 12,4 & 5,89 & 1,55 & 0,93 & 31 \\
\hline & Tidak Sesuai & 2,31 & 2,8 & 1,33 & 0,35 & 0,21 & 7 \\
\hline & Sangat Tidak Sesuai & 0,66 & 0,8 & 0,38 & 0,1 & 0,06 & 2 \\
\hline \multicolumn{2}{|c|}{ Total } & 33 & 40 & 19 & 5 & 3 & 100 \\
\hline
\end{tabular}

Hipotesis : $H_{0}:{ }_{M}=0$ (Tidak ada pengaruh faktor pribadi dalam keputusan pembelian sepeda motor Honda pada CV.Anugrah Perdana Monginsidi Palu dengan menggunakan metode koefisien kontingensi).

$H_{1}: M \neq 0$ (Ada penagruh faktor pribadi dalam keputusan pembelian sepeda motor Honda).

Pasangan hipotesis di atas diuji dengan statistik Chi-Kuadrat. Dengan bantuan program SPSS 16, maka diperoleh nilai Chi-Kuadrat $\left(X^{2}\right)=73.764$.

Tabel 5 : Frekuensi Observasi Pengaruh Faktor Psikologis

\begin{tabular}{|c|c|c|c|c|c|c|c|}
\hline \multirow{2}{*}{\multicolumn{2}{|c|}{ Psikologis }} & \multicolumn{5}{|c|}{ Keputusan Pembelian } & \multirow{3}{*}{$\begin{array}{c}\text { Tota } \\
17\end{array}$} \\
\hline & & \multirow{2}{*}{$\begin{array}{l}\text { SS } \\
13\end{array}$} & \multirow{2}{*}{$\begin{array}{l}S \\
4 \\
\end{array}$} & \multirow{2}{*}{$\begin{array}{l}\mathrm{N} \\
0\end{array}$} & \multirow{2}{*}{$\begin{array}{c}\text { TS } \\
0\end{array}$} & \multirow{2}{*}{$\begin{array}{c}\text { STN } \\
0 \\
\end{array}$} & \\
\hline \multirow{5}{*}{1} & Sangat Baik & & & & & & \\
\hline & Baik & 6 & 17 & 1 & 0 & 1 & 25 \\
\hline & Cukup Baik & 10 & 26 & 3 & 0 & 0 & 39 \\
\hline & Tidak Baik & 7 & 5 & 2 & 1 & 0 & 15 \\
\hline & Sangat Tidak Baik & 1 & 3 & 0 & 0 & 0 & 4 \\
\hline \multicolumn{2}{|c|}{ Total } & 37 & 55 & 6 & 1 & 1 & 100 \\
\hline \multirow{5}{*}{2} & Sangat Baik & 22 & 15 & 2 & 0 & 0 & 39 \\
\hline & Baik & 10 & 30 & 1 & 0 & 1 & 42 \\
\hline & Cukup Baik & 4 & 10 & 3 & 0 & 0 & 17 \\
\hline & Tidak Baik & 0 & 0 & 0 & 1 & 0 & 1 \\
\hline & Sangat Tidak Baik & 1 & 0 & 0 & 0 & 0 & 1 \\
\hline \multicolumn{2}{|c|}{ Total } & 37 & 55 & 6 & 1 & 1 & 100 \\
\hline \multirow{2}{*}{3} & Sangat Baik & 26 & 23 & 1 & 0 & 0 & 50 \\
\hline & Baik & 8 & 27 & 2 & 0 & 1 & 38 \\
\hline
\end{tabular}




\begin{tabular}{|l|l|c|c|c|c|c|c|}
\multicolumn{1}{|c|}{} & Cukup Baik & 2 & 5 & 3 & 0 & 0 & 10 \\
\cline { 2 - 7 } & Tidak Baik & 0 & 0 & 0 & 1 & 0 & 1 \\
\cline { 2 - 8 } & Sangat Tidak Baik & 1 & 0 & 0 & 0 & 0 & 1 \\
\hline Total & 37 & 55 & 6 & 1 & 1 & 100 \\
\hline
\end{tabular}

Dari ketiga pertanyaan didominasi oleh jawaban setuju, yaitu sejumlah masingmasing 55 responden. Hal ini menunjukan bahwa responden pada umumnya menyatakan setuju jika membeli sepeda motor Honda karena tertarik dengan iklan produk tersebut, mengetahui dengan baik informasi mengenai kualitas dan yakin terhadap ketahanan produknya.

Tabel 6 : Frekuensi Harapan Pengaruh Faktor Psikologis

\begin{tabular}{|c|c|c|c|c|c|c|c|}
\hline & \multirow{2}{*}{ Psikologis } & \multicolumn{5}{|c|}{ Keputusan Pembelian } & \multirow{2}{*}{ Total } \\
\hline & & SS & S & $\mathrm{N}$ & TS & STN & \\
\hline \multirow{5}{*}{1} & Sangat Baik & 6,29 & 9,35 & 1,02 & 0,17 & 0,17 & 17 \\
\hline & Baik & 9,25 & 13,75 & 1,5 & 0,25 & 0,25 & 25 \\
\hline & Cukup Baik & 14,43 & 21,45 & 2,34 & 0,39 & 0,39 & 39 \\
\hline & Tidak Baik & 5,55 & 8,25 & 0,9 & 0,15 & 0,15 & 15 \\
\hline & Sangat Tidak Baik & 1,48 & 2,2 & 0,24 & 0,04 & 0,04 & 4 \\
\hline \multicolumn{2}{|c|}{ Total } & 37 & 55 & 6 & 1 & 1 & 100 \\
\hline \multirow{5}{*}{2} & Sangat Baik & 14,43 & 21,45 & 2,34 & 0,39 & 0,39 & 39 \\
\hline & Baik & 15,54 & 23,1 & 2,52 & 0,42 & 0,42 & 42 \\
\hline & Cukup Baik & 6,29 & 9,35 & 1,02 & 0,17 & 0,17 & 17 \\
\hline & Tidak Baik & 0,37 & 0,55 & 0,01 & 0,01 & 0,01 & 1 \\
\hline & Sangat Tidak Baik & 0,37 & 0,55 & 0,01 & 0,01 & 0,01 & 1 \\
\hline \multicolumn{2}{|c|}{ Total } & 37 & 55 & 6 & 1 & 1 & 100 \\
\hline \multirow{5}{*}{3} & Sangat Baik & 18,5 & 27,5 & 3 & 0,5 & 0,5 & 50 \\
\hline & Baik & 14,06 & 20,9 & 2,28 & 0,38 & 0,38 & 38 \\
\hline & Cukup Baik & 3,7 & 5,5 & 0,6 & 0,1 & 0,1 & 10 \\
\hline & Tidak Baik & 0,37 & 0,55 & 0,06 & 0,01 & 0,01 & 1 \\
\hline & Sangat Tidak Baik & 0,37 & 0,55 & 0,06 & 0,01 & 0,01 & 1 \\
\hline \multicolumn{2}{|c|}{ Total } & 37 & 55 & 6 & 1 & 1 & 100 \\
\hline
\end{tabular}

Hipotesis : $H_{0}:{ }_{M}=0$ (Tidak ada pengaruh faktor psikologis dalam keputusan pembelian sepeda motor Honda pada CV.Anugrah Perdana Monginsidi Palu dengan menggunakan metode koefisien kontingensi).

$H_{1}: M \neq 0$ (Ada pengaruh faktor psikologis dalam keputusan pembelian sepeda motor Honda). 
Pasangan hipotesis di atas diuji dengan statistik Chi-Kuadrat. Dengan bantuan program SPSS 16, maka diperoleh nilai Chi-Kuadrat $\left(X^{2}\right)=98.662$.

Tabel 7 : Frekuensi Observasi Pengaruh Faktor Sosial

\begin{tabular}{|c|c|c|c|c|c|c|c|}
\hline & \multirow{2}{*}{ Sosial } & \multicolumn{5}{|c|}{ Keputusan Pembelian } & \multirow{3}{*}{$\begin{array}{c}\text { Total } \\
6\end{array}$} \\
\hline & & \multirow{2}{*}{$\frac{\text { SS }}{6}$} & \multirow{2}{*}{$\begin{array}{l}S \\
0\end{array}$} & \multirow{2}{*}{$\frac{N}{0}$} & \multirow{2}{*}{$\begin{array}{c}\text { TS } \\
0\end{array}$} & \multirow{2}{*}{$\begin{array}{c}\text { STN } \\
0\end{array}$} & \\
\hline \multirow{5}{*}{1} & Sangat Berpengaruh & & & & & & \\
\hline & Berpengaruh & 10 & 6 & 0 & 0 & 0 & 16 \\
\hline & Cukup Berpengaruh & 20 & 14 & 2 & 0 & 2 & 38 \\
\hline & Tidak Berpengaruh & 17 & 8 & 1 & 1 & 0 & 27 \\
\hline & Sangat Tidak Berpengaruh & 11 & 2 & 0 & 0 & 0 & 13 \\
\hline \multicolumn{2}{|c|}{ Total } & 64 & 30 & 3 & 1 & 2 & 100 \\
\hline \multirow{5}{*}{2} & Sangat Berpengaruh & 22 & 3 & 1 & 0 & 0 & 26 \\
\hline & Berpengaruh & 28 & 18 & 0 & 1 & 0 & 47 \\
\hline & Cukup Berpengaruh & 11 & 6 & 2 & 0 & 2 & 21 \\
\hline & Tidak Berpengaruh & 3 & 3 & 0 & 0 & 0 & 6 \\
\hline & Sangat Tidak Berpengaruh & 0 & 0 & 0 & 0 & 0 & 0 \\
\hline \multicolumn{2}{|c|}{ Total } & 64 & 30 & 3 & 1 & 2 & 100 \\
\hline \multirow{5}{*}{3} & Sangat Berpengaruh & 6 & 1 & 0 & 0 & 0 & 7 \\
\hline & Berpengaruh & 16 & 6 & 0 & 0 & 0 & 22 \\
\hline & Cukup Berpengaruh & 21 & 14 & 2 & 1 & 2 & 40 \\
\hline & Tidak Berpengaruh & 14 & 9 & 1 & 0 & 0 & 24 \\
\hline & Sangat Tidak Berpengaruh & 7 & 0 & 0 & 0 & 0 & 7 \\
\hline \multicolumn{2}{|c|}{ Total } & 64 & 30 & 3 & 1 & 2 & 100 \\
\hline
\end{tabular}

Dari ketiga pertanyaan tersebut didominasi oleh jawaban sangat setuju, yaitu sejumlah masing-masing 64 responden. Hal ini menunjukan bahwa responden pada umumnya menyatakan sangat setuju jika membeli sepeda motor Honda karena dipengaruhi lingkungan pergaulan, pengalaman dari anggota keluarga sebelumnya serta peran dan status dalam masyarakat.

Tabel 8 : Frekuensi Harapan Pengaruh Faktor Sosial

\begin{tabular}{|c|c|c|c|c|c|c|c|}
\hline & \multirow{2}{*}{ Sosial } & \multicolumn{5}{|c|}{ Keputusan Pembelian } & \multirow{2}{*}{ Total } \\
\hline & & SS & $S$ & $\mathrm{~N}$ & TS & STN & \\
\hline \multirow{5}{*}{1} & Sangat Berpengaruh & 3,84 & 1,8 & 0,18 & 0,06 & 0,12 & 6 \\
\hline & Berpengaruh & 10,24 & 4,8 & 0,48 & 0,16 & 0,32 & 16 \\
\hline & Cukup Berpengaruh & 24,32 & 11,4 & 1,14 & 0,38 & 0,76 & 38 \\
\hline & Tidak Berpengaruh & 17,28 & 8,1 & 0,81 & 0,27 & 0,54 & 27 \\
\hline & Sangat Tidak Berpengaruh & 8,32 & 3,9 & 0,39 & 0,13 & 0,26 & 13 \\
\hline \multicolumn{2}{|c|}{ Total } & 64 & 30 & 3 & 1 & 2 & 100 \\
\hline
\end{tabular}




\begin{tabular}{|c|l|c|c|c|c|c|c|}
\multirow{7}{*}{} & Sangat Berpengaruh & 16,64 & 7,8 & 0,78 & 0,26 & 0,52 & 26 \\
\cline { 2 - 8 } & Berpengaruh & 30,08 & 14,1 & 1,41 & 0,47 & 0,94 & 47 \\
\cline { 2 - 8 } & Cukup Berpengaruh & 13,44 & 6,3 & 0,63 & 0,21 & 0,42 & 21 \\
\cline { 2 - 8 } & Tidak Berpengaruh & 3,84 & 1,8 & 0,18 & 0,06 & 0,12 & 6 \\
\cline { 2 - 8 } & Sangat Tidak Berpengaruh & 0 & 0 & 0 & 0 & 0 & 0 \\
\hline \multirow{2}{*}{ Total } & & 64 & 30 & 3 & 1 & 2 & 100 \\
\hline \multirow{3}{*}{3} & Sangat Berpengaruh & 4,48 & 2,1 & 0,21 & 0,07 & 0,14 & 7 \\
\cline { 2 - 8 } & Berpengaruh & 14,08 & 6,6 & 0,66 & 0,22 & 0,44 & 22 \\
\cline { 2 - 8 } & Cukup Berpengaruh & 25,6 & 12 & 1,2 & 0,4 & 0,8 & 40 \\
\cline { 2 - 8 } & Tidak Berpengaruh & 15,36 & 7,2 & 0,72 & 0,24 & 0,48 & 24 \\
\cline { 2 - 8 } & Sangat Tidak Berpengaruh & 4,48 & 2,1 & 0,21 & 0,07 & 0,14 & 7 \\
\hline \multirow{2}{*}{ Total } & & 64 & 30 & 3 & 1 & 2 & 100 \\
\hline
\end{tabular}

Hipotesis : $H_{0}:{ }_{M}=0$ (Tidak ada pengaruh faktor sosial dalam keputusan pembelian sepeda motor Honda pada CV.Anugrah Perdana Monginsidi Palu dengan menggunakan metode koefisien kontingensi).

$H_{1}: M \neq 0$ (Ada pengaruh faktor sosial dalam keputusan pembelian sepeda motor Honda).

Pasangan hipotesis di atas diuji dengan statistik Chi-Kuadrat. Dengan bantuan program SPSS 16, maka diperoleh nilai Chi-Kuadrat $\left(X^{2}\right)=36.675$.

\subsection{Koefisien Kontingensi}

Untuk mengetahui besarnya pengaruh faktor - faktor tersebut dalam keputusan pembelian sepeda motor, maka perhitungan uji Chi-kuadrat di atas digunakan rumus koefisien kontingensi C. Dalam bentuk tabel dapat dilihat sebagai berikut :

Tabel 9 : Nilai koefisien kontingensi masing-masing faktor

\begin{tabular}{|l|l|l|}
\hline No & Faktor-faktor yang mempengaruhi & Harga C \\
\hline 1 & Faktor Budaya & 0,477 \\
\hline 2 & Faktor Pribadi & 0,651 \\
\hline 3 & Faktor Psikologis & 0,704 \\
\hline 4 & Faktor Sosial & 0,518 \\
\hline
\end{tabular}

Dari tabel di atas dapat diketahui bahwa faktor psikologis mempunyai harga $C$ yang lebih besar. Hal ini menunjukan faktor psikologis lebih berpengaruh dibandingkan dengan faktor kebudayaan, pribadi dan sosial.

Di peroleh keeratan hubungan antara faktor kebudayaan, pribadi, psikologis dan sosial sebagai berikut : 
$C_{\text {Max }}=\sqrt{\frac{4-1}{4}}=0,866$

Jadi nilai koefisien kontingensi maksimumnya adalah 0,866 . Jika nilai $\mathrm{C}$ mendkati nilai $C_{\text {Max }}$, maka terdapat hubungan yang sangat berpengaruh.

Kuatnya hubungan antara faktor kebudayaan, pribadi, psikologis dan sosial digunakan rumus persamaan ditampilakan sebagai berikut :

Tabel 10 : Nilai Indeks Kuat Hubungan ( $r$ )

\begin{tabular}{|l|l|l|}
\hline Faktor yang mempengaruhi & $\mathrm{IKH}(\mathrm{r})$ & Interpetasi Kualitatif \\
\hline Budaya & 0,581 & Sedang \\
Pribadi & 0,515 & Sedang \\
Psikologis & 0,346 & Lemah \\
Sosial & 0,317 & Lemah \\
\hline
\end{tabular}

Dengan memperhatikan Tabel di atas, terlihat bahwa faktor yang paling besar memberikan pengaruh adalah faktor budaya dengan nilai 0.581 dan faktor pribadi dengan nilai 0,515 . Hal ini menunjukan bahwa kuatnya hubungan antara faktor budaya dan faktor pribadi lebih mempengaruhi konsumen dalam keputusan pembelian sepeda motor Honda.

\section{KESIMPULAN}

Berdasarkan hasil penelitian mengenai faktor yang mempengaruhi konsumen dalam keputusan pembelian sepeda motor Honda di CV. Anugerah Perdana Monginsidi Palu yang telah dibahas serta perhitungan statistik yang dilakukan, maka penulis menarik kesimpulan sebagai berikut :

1. Uji Chi-kuadrat dari tiap variabel $\mathrm{X}$ (faktor-faktor) diperoleh bahwa faktor kebudayaan dengan nilai peluang 0,021 , faktor pribadi dengan nilai peluang 0,000 , faktor psikologis dengan nilai peluang 0,000 dan faktor sosial dengan nilai peluang 0,002 secara signifikan berpengaruh terhadap keputusan pembelian sepeda motor Honda di CV. Anugerah Perdana Monginsi di Palu Karena nilai peluang dari ke empat faktor tersebut lebih kecil dari taraf signifikan $(0,05)$, maka hipotesis nol $\left(\mathrm{H}_{0}\right)$ ditolak. Artinya faktor kebudayaan, pribadi, psikologis dan sosial sangat mempengaruhi konsumen dalam keputusan pembelian sepeda motor Honda.

2. Berdasarkan nilai $C$ yang mendekati nilai $C_{\text {Max }}$ yang lebih dominan berpengaruh terhadap keputusan pembelian sepeda motor Honda di CV.Anugerah Perdana Monginsidi Palu adalah variabel faktor psikologis dengan nilai $(C)=0.704$ dari nilai $C_{\text {Max }}=0,866$.

\section{DAFTAR PUSTAKA}


[1]. Anggar. 2012. Analisis Pengaruh Harga, Kualitas Produk, dan Promosi terhadap Keputusan Pembelian Sepeda Motor Honda (Studi Kasus pada Konsumen di Kota Semarang). Proposal. Universitas Diponegoro.

[2]. Siregar, S. 2005. Statistik Terapan Untuk Penelitian. PT Grasindo. Jakarta.

[3]. Sugiyono. 2004. Statistika Untuk Penelitian, Cetakan III. CV Alfabeta. Bandung.

[4]. Sugiyono. 2010. Statistik non Parametrik, Cetakan VIII. CV Alfabeta. Bandung.

[5]. Suliyanto. 2005. Analisis Data dalam Aplikasi Pemasaran. Ghalia Indonesia. Bogor.

[6]. Umar, H. 2005. Metode Penelitian untuk Skripsi dan Tesis Bisnis, Edisi Baru. PT. Raja Grafindo Persada. Jakarta. 